\title{
Water Analysis and Natural Filter Implantation in the Riverine Community of Santo Antônio II Settlement from Capim Island
}

\author{
José F. S. Costa ${ }^{1 *}$, Charles dos Reis Silva ${ }^{1}$, Yvens Ely Martins Cordeiro ${ }^{1}$, Sebastião Gomes Silva ${ }^{2}$, Cristiane Gomes \\ Moraes $^{1}$, Sebastião M. S. Cordeiro ${ }^{2}$ \\ ${ }^{1}$ Faculdade de Educação no Campo-FADECAM, Campus Universitário de Abaetetuba, Universidade Federal do Pará \\ Abaetetuba, Pará, Brasil \\ ${ }^{2}$ Faculdade de Ciências Exatas e Naturais, Campus Universitário de Abaetetuba, Universidade Federal do Pará, Abaetetuba, \\ Pará, Brasil \\ *jfsc@ufpa.br
}

\begin{abstract}
The objective of the study was to analyse three distinct points to perform a physicochemical and bacteriological analysis of a well in the community of Santo Antônio and two streams Marintuba and Caratateua, in order to verify the potability of the water consumed by this riverine community. Analyses of the following parameters were performed: nitrogen, pH, total solids, turbidity, dissolved oxygen, BOD, apparent color, free residual chlorine, iron, sulfate, nitrate, total ammoniacal nitrogen, total alkalinity, odor, conductivity, acidity, coliforms thermotolerant and total coliforms. In addition to these analyses, a qualitative-descriptive questionnaire was carried out, with data collected from semi-structured interviews directed to 26 people in the community in order to ascertain information that will allow verifying that according to the 2914 Order of Potability of the Ministry of Health is used as the basis. The results of the analyses will give possibilities for the implantation of filters of natural use for the families through lectures of conscientization. Natural filters, due to their low cost, can contribute in the sense of helping the community and, at the same time, the preservation of the environment of that place. It concludes by offering suggestions for the community to have full knowledge of the usefulness of the filter, avoiding consumption of contaminated water.
\end{abstract}

Keywords- Marintuba; Caratateua; Water; Pollution; Filter

\section{INTRODUCTION}

Water is one of the important elements of Planet Earth, constituting an essential thing to every living being. In the water, the first life forms emerged, which only survived to the extent that they could develop physiological mechanisms, which allowed them to withdraw water from the environment and retain it in their own organisms. The water is also the element that gave rise to and sustains life on planet Earth. Without water, no plant or animal species, including man can survive. Nowadays, man does not care about the uncontrolled consumption of water, compromising the future and generating a great shortage of drinking water in the planet.

In addition to quantity, the quality of water also changes as a result of natural and anthropogenic causes, that is, caused by man's way of living and the model of economic development intensive in natural resources [1]. It is observed that 78\% of the brazilian water is located in the Amazon Forest Region, which corresponds to $54.5 \%$ of the national territory and is home to $5 \%$ of the population, resulting in a population density of $1 \mathrm{hab} / \mathrm{km}^{2}$. The remaining $22 \%$ are located in other regions of the country (45.5\% of the national territory), which concentrate $95 \%$ of the population and have demographic densities above 400 $\mathrm{hab} / \mathrm{km}^{2}$.

According to the National Water Agency [2], the establishment of a parameter that indicates water quality is an important tool to guide planning and management actions. Based on a study carried out in 1970 by the "National Sanitation Foundation" of the United States, the CETESB adapted and developed the "Water Quality Index" (IQA). The creation of the IQA was based on an opinion survey with the water quality experts that indicated the variables to be evaluated, the relative weight of each of them and the condition with which each parameter is presented according to a scale of values [3]. The parameters used in the calculation of the IQA are mostly indicators of contamination due to the release of domestic sewage.

The lack of effective water supply, sewage collection and treatment systems has a noticeable negative impact on the environmental quality of many water sources, as well as the health impacts of populations exposed to pollution and the environmental costs that will be accounted for in the future [4]. In order to have an idea of the seriousness of the situation, it is known that more than $60 \%$ of the urban sewage in Brazil is launched, without any treatment, in the waterways. Faced with this worrying picture, water cannot be treated in a way that is distant from man, society and environmental education.

The elaboration of this article is to show a very clear image about the potability of the water of the region that surrounds Capim's Island, within a language very accessible to the community involved in the context of the study area, so that an environmental education process can be promoted, through methods that will be determined in the course of the work and that will take into account the environmental characteristic of that region, because as will be seen in the field research, the region suffers as the environmental impacts caused by the flow of toxic gases and debris dumped in the rivers that bathe that region, 
moving fish and shrimp away.

The water potability test at the three analysed sites was carried out through chemical, physical-chemical and biological tests: conductivity, $\mathrm{pH}$, turbidity and acidity, total coliform counts, thermotolerant coliform counts, apparent color, total dissolved solids, taste, chloride, total hardness, iron, sulfate, nitrate, nitrite, total ammoniacal nitrogen, odor, total alkalinity and odor. These tests are fundamental for proving the water potability index of that region, so that it is possible, with this study, to evaluate the type of water being consumed by the community.

The aim of this study is to acquire new knowledge that helps in the intellectual formation and that can support the professional performance with the objective of offering a meaningful educational practice for the people that, in a direct way, recognizing the relevance and the primordial value of water, considered, as a symbol of life. Thus, the development of this study has as general objective, to provide data collection to search for future actions aimed at investigating the potability of water in the "Ilha do Capim" riverside community, analyzing the potability of the water used by the riverside community, serving as a research reference to improve this field, seeking a better quality of life for the local community.

In addition, with the investigations in this riverside community, UFPA-Campus-Abaetetuba, to open space to strengthen the connection between the university and the traditional population. With regard to the specific objectives, show that the three places where the research was carried out lack knowledge about the potability of the water, so that a conscientization project can be developed that will contribute to the local community, regarding the must have on water consumption; to compare the potability of groundwater and fluvial water used by the community based on an analysis obtained with samples taken from those sites in order to evaluate the degree of impurity; and involve the local community, aiming to pass on knowledge and techniques of treatment, reuse, preservation and valorization of water, in order to achieve correct consumption.

The methodology developed is divided into two parts: the first one, seeks to carry out a bibliographic research, tracing some relevant topics that lead the researcher to a much deeper level of knowledge, making him understand about the great importance that the water for society at large; the other part, as already mentioned, corresponds to a field survey, which investigates the three places from which the community draws water for consumption.

The study was based on the ordinance of the Ministry of Health $n^{\circ} 2914 / 11$ [5], human, because when untreated it can lead and cause contamination). The ordinance establishes the norms and responsibility, acting as a vehicle properly related to the control and surveillance of water for said infectious agent or through certain substances of human consumption, as well as its standard of potability [6].

In order to verify if the water consumed by the population meets the norms of public water supply, in terms of potability, it was tried to evaluate the risks that the systems of quantity and quality can offer to the local population.

\section{METHODOLOGY}

\section{A. The Research Trajectory}

For the accomplishment of this research were followed steps, as:

- Bibliographic research: phase that consisted of a wide survey and bibliographic study on the subject;

- Collection: Water samples were collected for analysis at the three points of the study;

- Fieldwork: survey of socio-environment community data through questionnaires,

- Laboratory work: Lassanches analytical laboratory - analyses of water and effluents. Conducting physical-chemical analyses in groundwater samples and usual water analysis methodologies;

- Data Treatment: From the data obtained in the field were made the graphs and tables;

- Interpretation: the results obtained in the previous stages were interpreted within the vision of environmental education, characterizing the framework of the region's water resources. The relationship with the local community was made from all the data obtained in the previous phases, in order to achieve the main objective of this study: environmental education and water potability;

- Conclusions and elaboration of the final text: This phase consisted in the elaboration of the main conclusions of the whole study and in the writing of the article.

\section{B. Location and History of Capim Island}

The Island of Capim began to be populated by people of Marajoara origin. The first activity developed was the animal and vegetal extractivism followed by the production of sugar cane (Saccharumofficinarum mart.).

Over time, there were also changes in cultural, organizational, political and economic aspects. After the 1960's most of the island's residents began to participate in local social organization. The first local social organization was the Ecclesial Base 
Community (CEB) called Santo Antônio. Today, in addition to the Santo Antônio community, the São Pedro community was created recently, on the Caratateua River, which also composes the island's organization. This organization operates from guidelines of the parish of the islands of Abaetetuba, belonging to the Catholic Church. In addition to these religious organizations, there are two Protestant-oriented Evangelical Churches on the island.

From the first decade of the 21st century, the island's social organization expanded after the emergence of the agroextractive settlement project called Santo Antônio II, created through the ordinance INCRA SR-01/G/n 055, December 16, 2005. Nowadays, as an instrument of organized representation, the residents also have the "Santo Antônio II Residents' Association", which was founded on November 28, 2005, for the purposes of access to Agrarian Reform policies, through this modality of settlement. In addition to the Association, the residents also participate in the Association of Residents of the Islands of Abaetetuba (AMIA), the Fishermen's Colony Z-14, and the Movement of the riverines of the Islands and Várzeas of Abaetetuba (MORRIVA) and the Movement of Affected by Dams (MAB). Fig. 1 shows the location of Capim Island, where the research was carried out, at the three collection points that served as a reference.

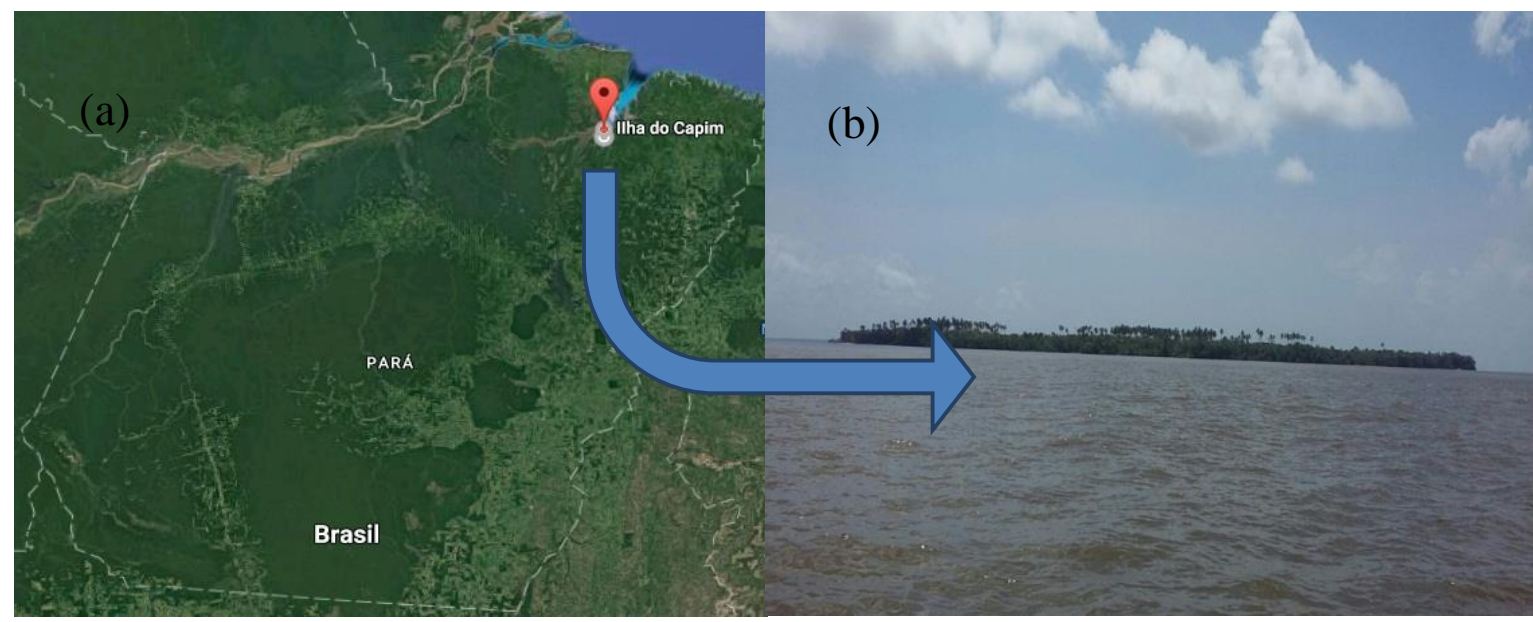

Fig. 1 Location and History of the search area (“a” Google Maps, 2017; "b” Author's Collection)

\section{Characterization of the Researched Space}

The main source of water supply in Capim Island is the wells, which are mostly of the Amazon type, less than 20 meters deep and seek to supply the deficiency of not having a general supply network in the Island. These wells are drilled manually, without any technical concern or hygiene care. Therefore, they are considered as potential sources of pollutants, which can contaminate the aquifer layers.

Even though a large part of the population of Capim Island does not use any type of treatment with water intended for consumption, $80 \%$ of the inhabitants of this Island; they do not have any special care, that is, the way the water is taken from the source that supplies the residences, is consumed, without first undergoing any kind of treatment, which makes this percentage of the population susceptible to waterborne diseases.

It was verified that the majority of the garbage of the Capim Island is burned or rejected in the areas of circumscription of the residences. What is interesting to note is that environmental education is not yet a constant among these residents, given, the number of people who recycle or who at least care in separating the garbage for recycling is minimal, reaching the percentage of $1 \%$. Collection by government management does not occur.

The number of inorganic waste produced is quite high; the most produced are metal, plastic, paper and glass. That alone would be sufficient reason to develop environmental education work on the Island, since it is known that all these materials take a long time to decompose, causing serious environmental risks. In addition, even if the amount of organic waste is less than the inorganic, this does not prevent or protect the population that can be acquired by attracting agents that cause them.

The data obtained revealed that: due to the lack of garbage collection in Capim Island, the residents burn the garbage or discharge it in the water course and vacant lots, causing damage to the environment.

\section{Interviews in the Community of Capim Island About Water Potability}

In this research, 26 people were interviewed with the objective of ascertaining the possible problems faced by the community regarding water consumption. The choice of collection sites took place around the island, in the three main points of access to the withdrawal of water for consumption. The second point was to consider people who lived for many years in that locality. 


\section{RESULTS AND DISCUSSION}

\section{A. Result of the Interview in the Community of the Grass Island on the Potability of Water}

According to the interviewees' answer, it is believed that water consumed daily affects most of the community, which according to the statistical method, about $96 \%$ are affected by diseases such as diarrhea, vomiting and fever, which according to the $66 \%$ of respondents state that it is due to water pollution. Another fact that is observed in this research concerns the scarcity of fish and shrimp, which because of the fluvial pollution, moved away from the rivers of the region. The finding of this fact, according to the chart above, is of the $40 \%$ of respondents. Regarding skin problems, such as itching, $93 \%$ claim to be due to water pollution. Thus, $100 \%$ of the interviewees affirm that the problems occurred in the community are caused by the implantation of mineral processing plants, surrounding the region, which pollutes both the air and the water, distancing fish and shrimp, affecting considerably the environment as Fig. 2 shows.

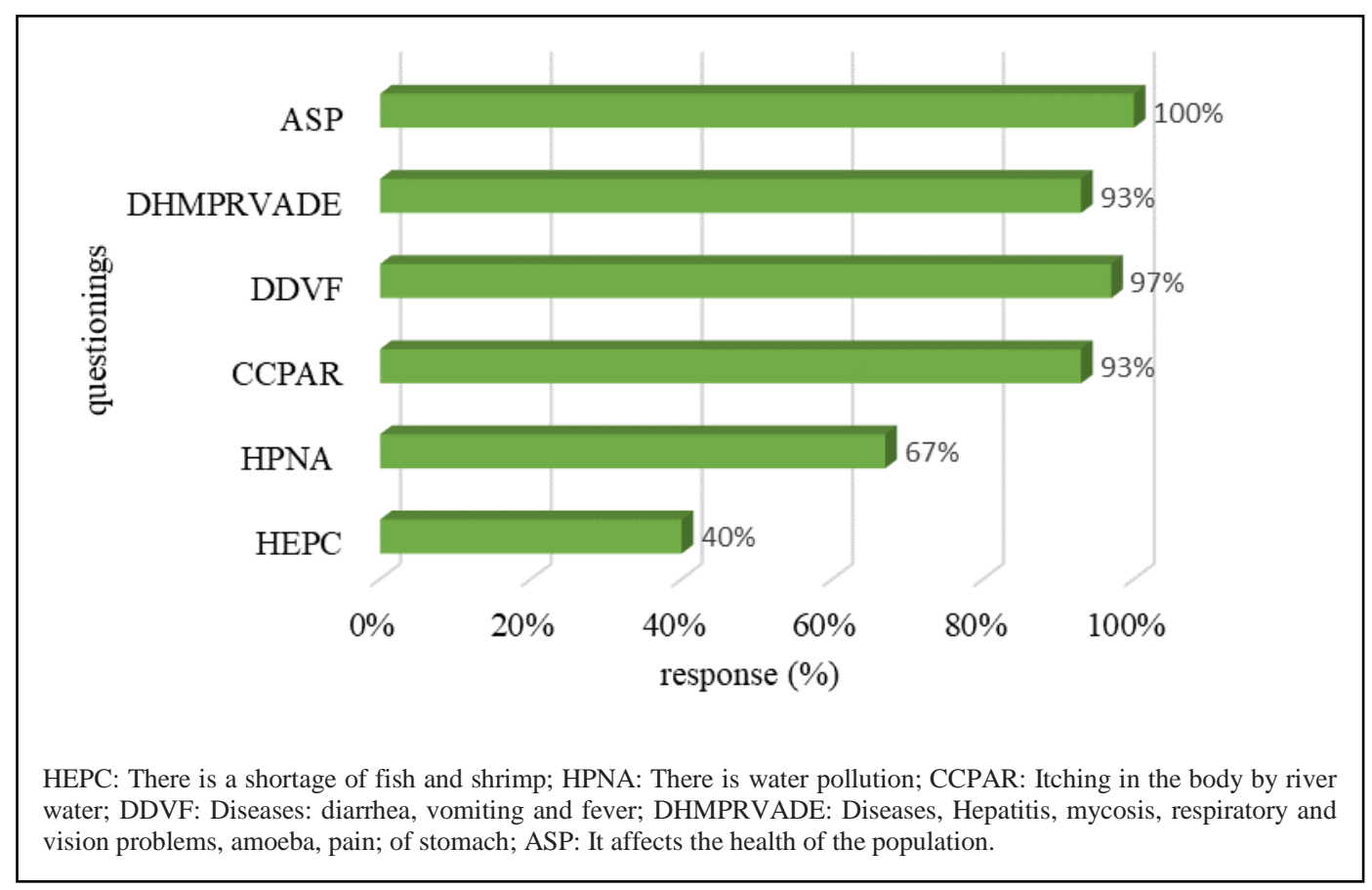

Fig. 2 Response on the consequences of solid waste dumped by factories in the rivers of the region.

About $100 \%$ of the interviewees were unanimous in agreeing that: the pernicious environmental changes were caused by the setting up of ore processing plants, which are responsible for the emission of gases that affect and degrade the environment. Many plants, such as açai trees, mango trees and many other species have been harmed by the emission of toxic fumes from factories.

In this way, one observes how big the problem is, that the community experiences: on the one hand the environmental changes affecting the natural growth of the fruits, the species of the flora; on the other, the scarcity of fish and shrimp in the riverside region. About $93 \%$ of the interviewees claim that there is no social project by the public power, that will solve the problem in the community, because, what is being taken into account in this research is the great problem that the community faces, one side the shortage of fish and shrimp; on the other, increased climate change from toxic gas pollutions, which emitted by neighbouring factories and kills some species of plants. This fact was confirmed by $47 \%$ of interviewees and observed in Fig. 3. 


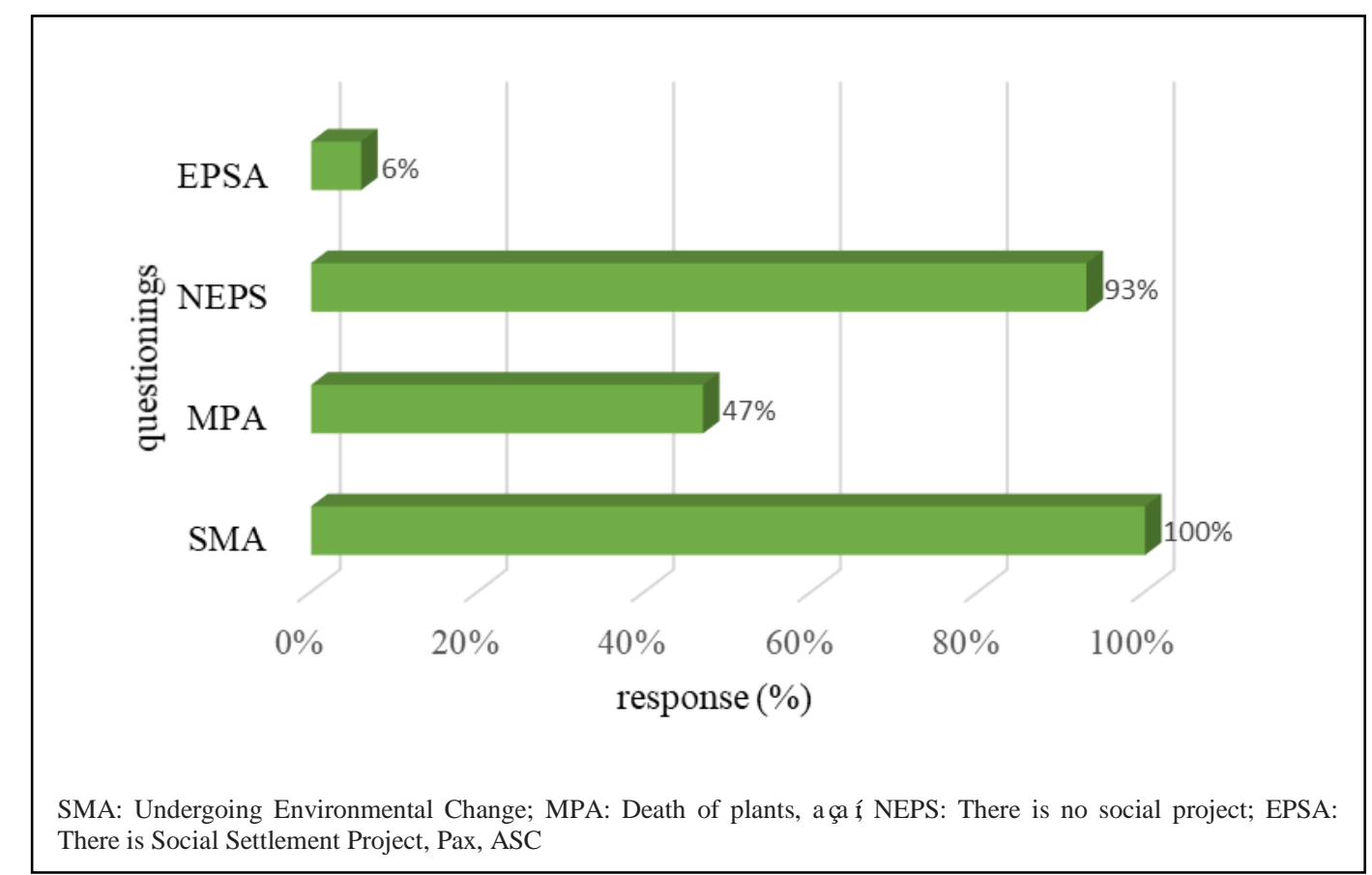

Fig. 3 Environmental changes, death of aquatic species and the question of social projects in the Capim Island community.

According to Fig. 4, 63\% of the interviewees who consume the water withdrawn directly from the river, which leads to the onset of the pathologies described above. There is also the $30 \%$ that uses water from the wells, and the $6 \%$ that uses neither water from the well nor from the river, using mineral water for consumption. Other $20 \%$ use water treatment and cleaning procedures, using hypochlorite (bleach water) and chlorine, as a possible solution to alleviate problems caused by water. According to this interview, there is a concern on the part of the community regarding the consumption of water, since the factory implantation brings a problem of concern to the community, which, although not having the necessary support from the public power, deals with the issues about the potability of water. It is necessary that certain measures can be taken to overcome this problem in the community. By the interview, only $6 \%$ of the interviewed ones are protected using mineral water.

It is necessary for the local population to mobilize and cover the public sector with a way of solving this problem, because this population is being harmed in every way: in the environmental issue, in the food shortage (fish and shrimp), in water pollution and environmental changes, which according to the interviewees, come from factories.

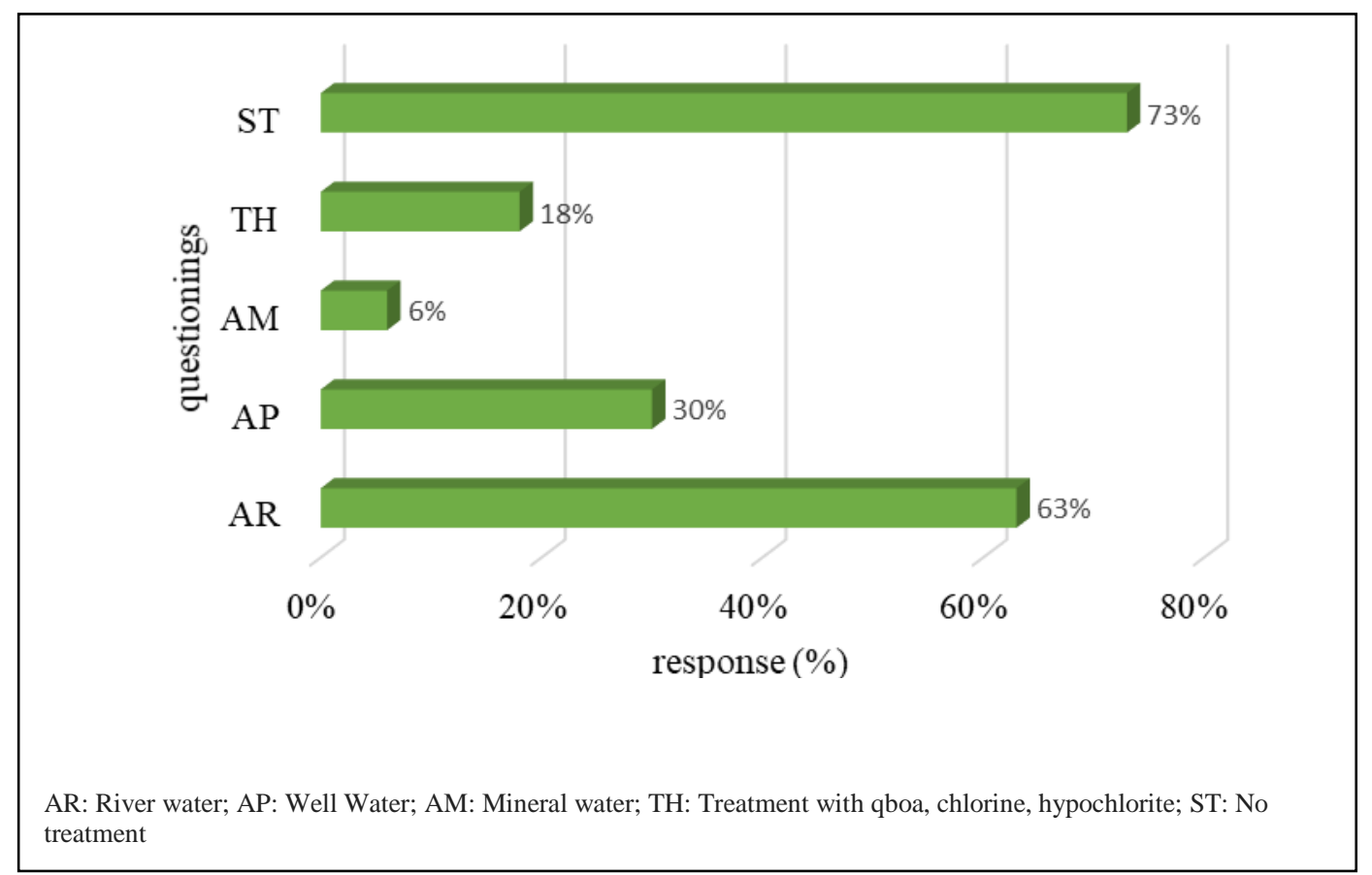

Fig. 4 How is the consumption of water by the residents of Capim Island. 
One of the greatest aggravating factors in this interview can be observed in this graph, where $97 \%$ of the interviewees say that there is contamination due to the implantation of the factories. In addition to this problem, there is no care taken by the community regarding the issue of correct disposal and disposal of waste. They pollute the river from which they take food, so the community and the factories are responsible for the scarcity of fish and shrimp, as polluted water changes the marine life and, the aquatic beings, the search for water with more oxygen is withdrawn. It is believed that if the president of this community, together with the government and other competent Government Agency, seek a way to raise awareness of the community, explaining through lectures the correct garbage collection, not letting them be dumped in rivers and streams, may the conscience of all of them, solve mainly the problem of garbage, since it was the duty of the municipal government of Abaetetuba to collect it. The Fig. 5 clearly demonstrates garbage collection and contamination.

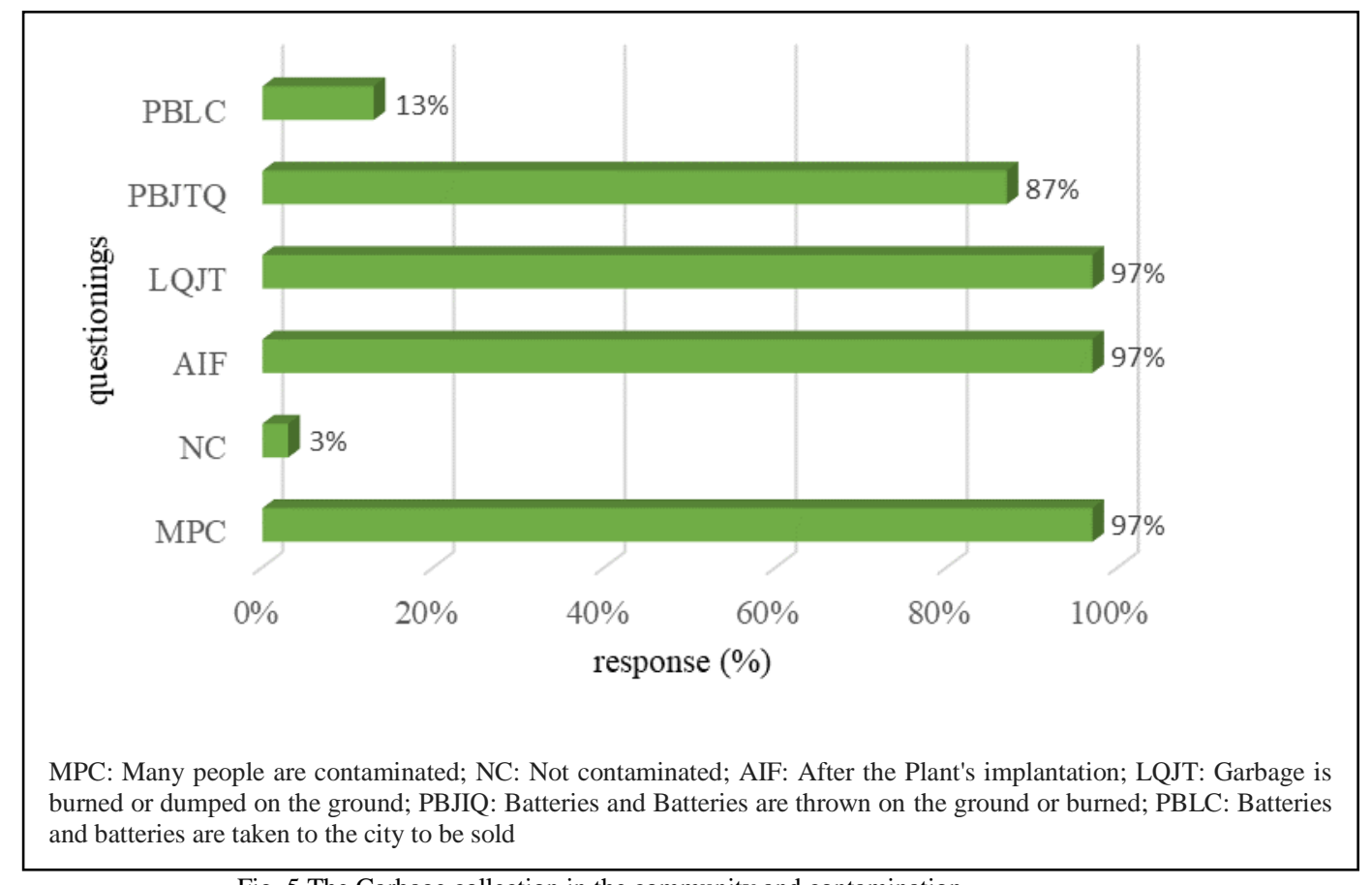

Fig. 5 The Garbage collection in the community and contamination.

Fig. 6 shows that the community does not have projects associated with the potability of water where consumption could happen in a much safer way. The community has, on the part of the local coordinators, some type of lectures, alerting on the contamination and diseases caused by contaminated water.

According to the interview, $93 \%$ affirm that the community does not receive any project from the public power to solve the present problem. This issue involves, in a certain way, political and economic interest, just because, the implantation of factories can cause serious damage to the population, which is subject to any type of pathology due to the emission of toxic gases that can affect the environment, the rivers and streams of the riverine areas, including the fish, as was observed in previous interviews. The community has the right to know the environmental risks and impacts that factory deployments can cause, and the public power has the role, along with other competent bodies to supervise and make feasible proposals and projects, that will ensure fewer risks to the surrounding communities. In this part of the research, it is observed that most of the interviewees claim that there is no kind of awareness-raising lecture. 


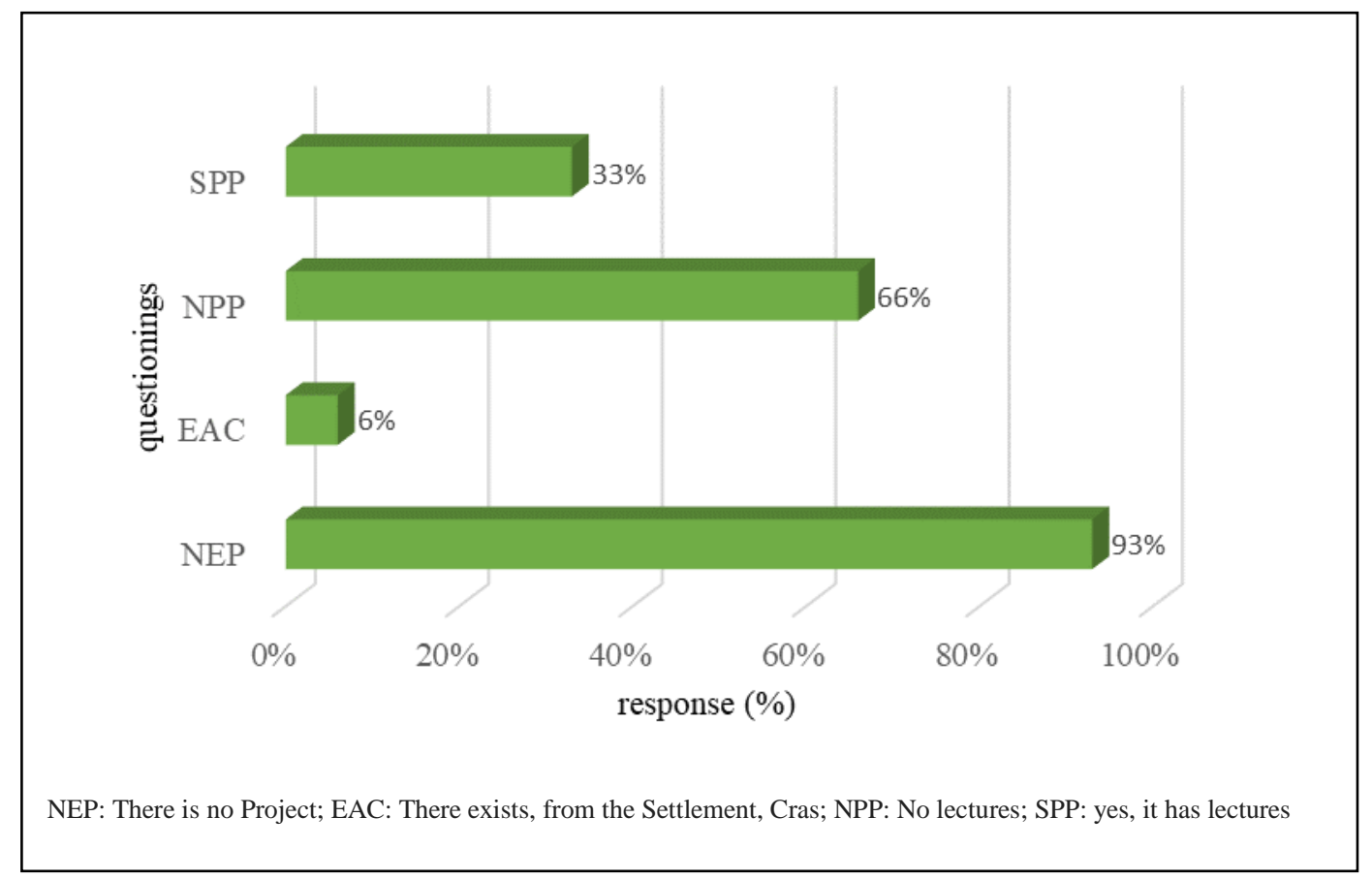

Fig. 6 Awareness Projects to the community about the danger of the Contamination.

\section{B. Results Obtained from the Laboratorial Analysis of Collected Points}

\section{1) Points of Analysis}

To do the research, three different sites in Capim Island were investigated and analysed as shown in Fig. 7. The sampling points were chosen in order to obtain a better distribution of the points in the work area and ease of access to them.

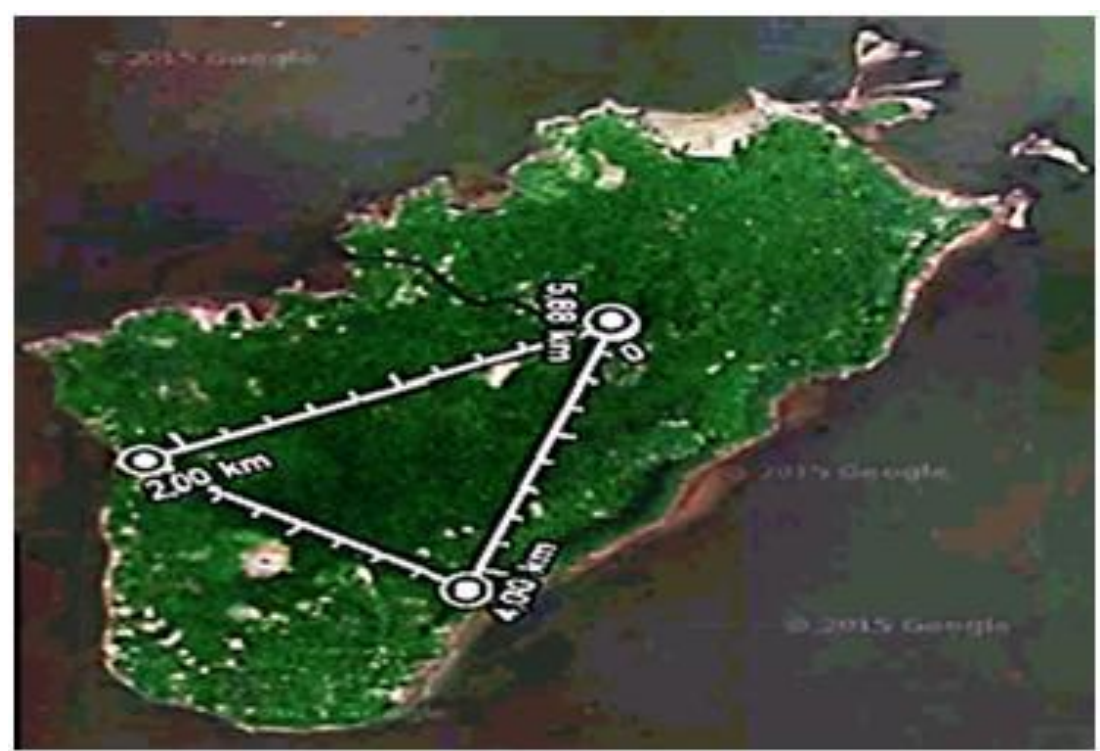

Fig. 7 Location points from where it was taken to the waters for analysis Source (World Map)

\section{2) Collection Procedures}

It was collected between January 2015 and February 2016. The samples were collected in duplicates, where several parameters were analysed for the evaluation of water potability.

For the analysis of the physical and chemical parameters, the samples were collected in $500 \mathrm{ml}$ glass containers, where the environment was made. Regarding the biological parameters, $500 \mathrm{ml}$ glass vials were used, duly autoclaved and analysed before completing 24 hours of storage. The collections were carried out in the morning and soon, placed in Styrofoam with ice and taken to Belem for analysis. The number of samples complied with the provisions of Ordinance No. 2914, December 12, 2011, of the Ministry of Health. 


\section{3) Parameters Analysed}

In this study the following parameters were analysed:

\section{The Hydrogenation Potential (pH)}

The Hydrogentaion potential represents the concentration of hydrogen ions $\left(\mathrm{H}^{+}\right)$, which indicates the acidity, neutrality or alkalinity condition of the water.

According to Von Sperling [7], this content may be of natural origin, through the dissolution of rocks, absorption of gases from the atmosphere, oxidation of organic matter and photosynthesis. It can also have anthropogenic origin, through domestic evictions (oxidation of organic matter) and industrial dumping (for example, acidic tank washing).

\section{Sum of the Contents of All Mineral Constituents (STD)}

It refers to the sum of the contents of all the mineral constituents present in the water, that is, it represents the concentration of all the dissolved material in the water, whether or not it is volatile.

\section{Alkalinity}

It is the total measure of the substances present in water, capable of neutralizing acids. In groundwater the alkalinity is mainly due to carbonates and bicarbonates and, secondarily, to hydroxide ions, silicates, borates, phosphates and ammonia [7] (VON SPERLING, 1997). $\mathrm{CaCO}_{3}$.

Total alkalinity is the sum of the alkalinity produced by all these ions present in a water, being expressed in $\mathrm{mg} / \mathrm{L}$ de

\section{Sodium $\left(\mathrm{Na}^{+}\right)$}

Sodium is a chemical element almost usually present in groundwater. Its major source minerals (plagioclase feldspars) are poorly resistant to intemperate processes, especially chemicals. The salts formed in these processes are very soluble. In groundwater, the sodium content varies between 0.1 and $100 \mathrm{mg} / \mathrm{L}$, and there is a gradual enrichment of this metal from the recharge zones [8].

\section{Chlorides ( $\left.\mathrm{Cl}^{-}\right)$}

Chlorine is present in groundwater at levels below $100 \mathrm{mg} / \mathrm{L}$, forming very soluble compounds and tending to be enriched, together with sodium, from the groundwater recharge zones. Anomalous contents are indicators of contamination by seawater, and by landfills [8].

\section{Nitrate $\left(\mathrm{NO}^{3-}\right)$ e Nitrite $\left(\mathrm{NO}^{2-}\right)$}

Nitrates can derive from sewage and its presence in water is evidence of contamination. However, such contamination in groundwater can only occur if, at the same time, chloride is present. In groundwater, they occur in levels, generally below $5 \mathrm{mg} / \mathrm{L}$ [7].

They are toxic substances that can be present naturally in various foods, plant, animal and in the water, in addition, can compete with iron through the free oxygen in the bloodstream. It is worth mentioning that, in fish and other aquatic animal systems, nitrites and nitrates, in general, do not affect production and productivity. However, the oxidation of ammonia to nitrate causes a decrease in the $\mathrm{pH}$ of the water. This acidification of culture water can cause considerable economic losses if the $\mathrm{pH}$ falls below 6.5 and $\mathrm{pH}$ below 4.0 causes fish mortality [9]. Low $\mathrm{O}_{2}$ dissolved, less than $1.0 \mathrm{~mL} / \mathrm{L}$, cause methemoglobinemia problems [10]. The lethal concentration of nitrite in the cultivate water varies according to species, type of water (sweet, salty, brackish) and age of the animals.

\section{4) Results of Laboratory Analyses of the Caratateua River Sample}

Tables 1, 2 and 3 present information about the sample collected in Caratateua River and the results of the analyses.

TABLE 1 COLLECTED SAMPLE INFORMATION

\begin{tabular}{|l|l|}
\hline \multicolumn{2}{|c|}{ Sample ID:5359- Sample $\mathbf{N}^{\circ}: \mathbf{8 5 4 - 1 / 2 0 1 6 . 0 - F l u v i a l ~ 2 ~ - ~ C a p i m ~ I s l a n d ~ - ~ C a p i m ~ - ~ A b a e t e t u b a - S t r e a m ~ C a r a t a t e u a ~}$} \\
\hline Type de Sample: Âgua Superficial & Matriz : Água Superficial \\
\hline Date of Collection: 01/27/2016 / 09:03h & Receipt Date:03/12/2016/11:15h \\
\hline $\begin{array}{l}\text { Collect Point: Fluvial- Capim Island Abaetetuba - } \\
\text { Stream Caratateua }\end{array}$ & Observation: Sample collection and delivered by applicant. \\
\hline $\begin{array}{l}\text { Quantity Analysis FQ/Micro: Micrological Chemical } \\
\text { physicist }\end{array}$ & Quantity and Physical-Chemical Analysis: 1 \\
\hline Quantity of Microbiological Analysis : 1 & --- \\
\hline
\end{tabular}


TABLE 2 ANALYTICAL RESULTS

\begin{tabular}{|l|c|c|c|c|c|c|}
\hline \multicolumn{7}{|c|}{ Analytical Laboratory } \\
\hline Analyse & Unit & Result & LDM & LQP & IM & IdM \\
\hline $\mathrm{pH}$ & & 7,01 & & & & 1067 \\
\hline Turbidity & $\mathrm{uT}$ & 16,00 & & & & 1074 \\
\hline Apparent Color & $\mathrm{uH}$ & 145,0 & 3 & 3 & & 1083 \\
\hline Free Residual Chlorine & $\mathrm{mg} / \mathrm{L}$ & 0,00 & 0,04 & 0,04 & & 1086 \\
\hline Taste & & Não Objetável & & & & 1178 \\
\hline Thermotolerant Coliform & $\mathrm{NMP} / 100 \mathrm{ml}$ & Presença & & & & 1193 \\
\hline Total Coliforms & $\mathrm{NMP} / 100 \mathrm{ml}$ & Presença & & & & 1193 \\
\hline Chloride & $\mathrm{mg} / \mathrm{L}$ & 8,03081 & 0,05 & 0,05 & & 1197 \\
\hline Total Hardness & $\mathrm{mg} / \mathrm{L}$ & 16,017 & 1,8 & 1,8 & & \\
\hline Iron & $\mathrm{mg} / \mathrm{L}$ & 0,41 & 0,002 & 0,002 & & 1197 \\
\hline Sulfate & $\mathrm{mg} / \mathrm{L}$ & 4,30116 & 0,05 & 0,05 & & 1197 \\
\hline Nitrate & $\mathrm{mg} / \mathrm{L}$ & 0,1 & 0,005 & 0,005 & & 1197 \\
\hline Nitrite & $\mathrm{mg} / \mathrm{L}$ & 0,03717 & 0,003 & 0,003 & & 1197 \\
\hline Total Ammoniacal Nitrogen & $\mathrm{mg} / \mathrm{L}$ & 0,0212 & 0,002 & 0,002 & & 1197 \\
\hline Total Alkalinity & $\mathrm{mg} \mathrm{CaCO} / \mathrm{L}$ & 100,52 & 2,6 & 2,6 & & \\
\hline Odor & $\mathrm{Intensity}$ & Not Applicable & & & & 1197 \\
\hline Conductivity & $\mathrm{uS} / \mathrm{cm}{ }^{2}$ & 57,07 & 0,005 & 0,005 & & 1197 \\
\hline Dissolved oxygen & $\mathrm{Mg} / \mathrm{L}$ & 7,97 & 0,003 & 0,003 & & 1200 \\
\hline Acidity & $\mathrm{Mg} / \mathrm{L}$ & 105,228 & 0,002 & 0,002 & & 1057 \\
\hline Total Dissolved Solids & $\mathrm{Mg} / \mathrm{L}$ & 29,02 & 2,6 & 2,6 & & 1068 \\
\hline DBO & $\mathrm{Mg} / \mathrm{L}$ & 23,05 & & & & 1079 \\
\hline
\end{tabular}

SUBTITLE: LDM: Limit of detection of the method of analysis. LQP: limit of qualification practiced. IM: Uncertainty of mediation. IdM: Method Identification. NA: Not detected (<LQP). NO: Not Applicable.

TABLE 3 SPECIFICATIONS AND OPINIONS

\begin{tabular}{|c|c|c|c|c|c|}
\hline \multicolumn{6}{|c|}{ Complete Ordinance 2.914} \\
\hline \multicolumn{2}{|c|}{ Analysis } & Unit & Limit & \multicolumn{2}{|c|}{ Opinion } \\
\hline \multicolumn{2}{|c|}{ Chloride } & $\mathrm{mg} / \mathrm{L}$ & Up to 250 & \multicolumn{2}{|c|}{ Conforming } \\
\hline \multicolumn{2}{|c|}{ Total Hardness } & $\mathrm{mg} / \mathrm{L}$ & Up to 500 & \multicolumn{2}{|c|}{ Conforming } \\
\hline \multicolumn{2}{|l|}{ Iron } & $\mathrm{mg} / \mathrm{L}$ & Up to 0,3 & \multicolumn{2}{|c|}{ Not Conforming to Upper Limit. } \\
\hline \multicolumn{2}{|l|}{$\mathrm{pH}$} & & From 6,0 to 9,5 & \multicolumn{2}{|c|}{ Conforming } \\
\hline \multicolumn{2}{|c|}{ Turbidity } & $\mathrm{uT}$ & Up to 5,0 & \multicolumn{2}{|c|}{ Conforming } \\
\hline \multicolumn{2}{|l|}{ Nitrate } & $\mathrm{mg} / \mathrm{L}$ & Up to 10,0 & Confor & \\
\hline \multicolumn{2}{|l|}{ Nitrite } & $\mathrm{mg} / \mathrm{L}$ & Up to 1,0 & \multicolumn{2}{|c|}{ Conforming } \\
\hline \multicolumn{2}{|c|}{ Total Ammoniacal Nitrogen } & $\mathrm{mg} / \mathrm{L}$ & Up to 1,5 & \multicolumn{2}{|c|}{ Conforming } \\
\hline \multicolumn{2}{|c|}{ Apparent Color } & $\mathrm{uH}$ & Up to 15,0 & \multicolumn{2}{|c|}{ Conforming } \\
\hline \multicolumn{2}{|l|}{ Sulfate } & $\mathrm{mg} / \mathrm{L}$ & Up to 250 & \multicolumn{2}{|c|}{ Conforming } \\
\hline \multicolumn{2}{|l|}{ Taste } & Intensidade & Not Applicable & \multicolumn{2}{|c|}{ Conforming } \\
\hline \multicolumn{2}{|c|}{ Thermotolerant Coliform } & $\mathrm{NMP} / 100 \mathrm{ml}$ & Absence & \multicolumn{2}{|c|}{ No Conforming } \\
\hline \multicolumn{2}{|c|}{ Total Coliforms } & $\mathrm{NMP} / 100 \mathrm{ml}$ & Absence & \multicolumn{2}{|c|}{ No Conforming } \\
\hline \multicolumn{2}{|l|}{ Odor } & Intensidade & Not Applicable & \multicolumn{2}{|c|}{ Conforming } \\
\hline \multicolumn{2}{|c|}{ Total Dissolved Solids } & $\mathrm{mg} / \mathrm{L}$ & Up to 1000 & Confor & \\
\hline & & Methods o & Analysis and $\mathrm{Co}$ & nentary & \\
\hline IdM & Methods o & Analysis & Refer & nethod & Finalization Date \\
\hline 1067 & $\mathrm{pH}$ & & SMWW $22^{\circ} 4$ & & $03 / 02 / 2016 / 11: 16 \mathrm{~h}$ \\
\hline 1074 & Turbidity & & SMWW $22^{\circ} 2$ & & $03 / 02 / 2016 / 11: 17 \mathrm{~h}$ \\
\hline 1083 & Apparent Color & & SMWW $22^{\circ} 2$ & & $03 / 02 / 2016 / 11: 18 \mathrm{~h}$ \\
\hline 1086 & Free Residual Ch & rine & USEPA 330.5 & & $03 / 02 / 2016 / 11: 18 \mathrm{~h}$ \\
\hline 1178 & Taste & & SMWW $22^{\circ} 2$ & & 03/02/2016/11:19h \\
\hline 1193 & Qualitative Colif & & SMWW $22^{\circ} 9$ & & $03 / 02 / 2016 / 16: 05 \mathrm{~h}$ \\
\hline 1197 & Gallery & & Método Galler & 670 & $03 / 02 / 2016 / 11: 18 \mathrm{~h}$ \\
\hline 1200 & Odor & & SMWW $22^{\circ} 2$ & & $03 / 02 / 2016 / 11: 19 \mathrm{~h}$ \\
\hline 1057 & Conductivity & & SMWW $22^{\circ} 2$ & & $03 / 02 / 2016 / 11: 19 \mathrm{~h}$ \\
\hline 1068 & Dissolved oxygen & & SMWW $22^{\circ} 4$ & & $03 / 02 / 2016 / 11: 17 \mathrm{~h}$ \\
\hline 1079 & Acidity & & SMWW $22^{\circ} 2$ & & 03/02/2016/11:20h \\
\hline
\end{tabular}

\section{5) Results of Laboratory Analyses of the Sample of the Artesian Well of the Community of Santo Antonio II}

Tables 4, 5 and 6 present information about the sample of the artesian well of the community of Santo Antônio II and the results of the analyses. 
TABLE 4 COLLECTED SAMPLE INFORMATION

\begin{tabular}{|l|l|}
\hline \multicolumn{2}{|c|}{ Sample ID:5357- Sample N': 727/2016-S'1576178w'48.881113 } \\
\hline Type of Sample: Water for Consumption & Matrix: Well \\
\hline Collect Date: $27 / 01 / 2016 / 09: 34 \mathrm{~h}$ & Receipt Date: $02 / 12 / 2016 / 08: 57 \mathrm{~h}$ \\
\hline $\begin{array}{l}\text { Collect Point: Capim Island Abaetetuba Community } \\
\text { Santo Antônio II }\end{array}$ & Observation: Sample Collect and Delivered by the Applicant. \\
\hline $\begin{array}{l}\text { Amount of Analysis FQ/Micro: Micrologic Chemical } \\
\text { physicist }\end{array}$ & Quantity and Physical-Chemical Analysis: 1 \\
\hline Quantity of Microbiological Analysis:1 & \\
\hline
\end{tabular}

TABLE 5 ANALYTICAL RESULTS

\begin{tabular}{|c|c|c|c|c|c|c|}
\hline \multicolumn{7}{|c|}{ Analytical Laboratory } \\
\hline Analyse & Unit & Result & LDM & LQP & IM & IdM \\
\hline Conductivity & $\mu \mathrm{S} / \mathrm{cm}^{2}$ & 75,07 & & & & 1057 \\
\hline $\mathrm{pH}$ & & 6,05 & & & & 1067 \\
\hline Turbidity & uT & 0,02 & & & & 1074 \\
\hline Acidity & $\mathrm{mg} / \mathrm{L}$ & 138,084 & & & & 1079 \\
\hline Total Coliform Count & NMP/100ml & 17,00 & & & & 1081 \\
\hline Thermotolerant Coliform Count & $\mathrm{NMP} / 100 \mathrm{ml}$ & 17,00 & & & & 1081 \\
\hline Apparent Color & $\mathrm{uH}$ & 0 & 3 & 3 & & 1083 \\
\hline Total Dissolved Solids & $\mathrm{mg} / \mathrm{L}$ & 38,06 & & & & 1131 \\
\hline Taste & Intensidade & Não Objetável & & & & 1178 \\
\hline Thermotolerant Coliform & NMP/100ml & Presença & & & & 1193 \\
\hline Total Coliforms & $\mathrm{NMP} / 100 \mathrm{ml}$ & Presença & & & & 1193 \\
\hline Chloride & $\mathrm{mg} / \mathrm{L}$ & 14,01674 & 0,05 & 0,05 & & 1197 \\
\hline Total Hardness & $\mathrm{mg} / \mathrm{L}$ & 13,46827 & 1,8 & 1,8 & & 1197 \\
\hline Iron & $\mathrm{mg} / \mathrm{L}$ & 0,45 & 0,002 & 0,002 & & 1197 \\
\hline Sulfate & $\mathrm{mg} / \mathrm{L}$ & 12,17151 & 0,05 & 0,05 & & 1197 \\
\hline Nitrate & $\mathrm{mg} / \mathrm{L}$ & 0,1 & 0,005 & 0,005 & & 1197 \\
\hline Nitrate & $\mathrm{mg} / \mathrm{L}$ & 0,05312 & 0,003 & 0,003 & & 1197 \\
\hline Total Ammoniacal Nitrogen & $\mathrm{mg} / \mathrm{L}$ & $<0,002$ & 0,002 & 0,002 & & 1197 \\
\hline Total Alkalinity & $\begin{array}{l}\mathrm{Mg} \\
\mathrm{CaCO}_{3} / \mathrm{L}\end{array}$ & 83,22 & 2,6 & 2,6 & & 1197 \\
\hline Odor & Intensity & Not Applicable & & & & 1200 \\
\hline
\end{tabular}

TABLE 6 SPECIFICATIONS AND OPINIONS

\begin{tabular}{|c|c|c|c|c|c|}
\hline \multicolumn{6}{|c|}{ Complete Ordinance 2.914} \\
\hline \multicolumn{2}{|c|}{ Analyse } & Unit & Limit & \multirow{2}{*}{\multicolumn{2}{|c|}{$\begin{array}{l}\text { Opinion } \\
\text { Conforming }\end{array}$}} \\
\hline \multicolumn{2}{|c|}{ Chloride } & $\mathrm{mg} / \mathrm{L}$ & Up to 250 & & \\
\hline \multicolumn{2}{|c|}{ Total Hardness } & $\mathrm{mg} / \mathrm{L}$ & Up to 500 & \multicolumn{2}{|c|}{ Conforming } \\
\hline \multicolumn{2}{|l|}{ Iron } & $\mathrm{mg} / \mathrm{L}$ & Up to 0,3 & \multicolumn{2}{|c|}{ Not Conforming to Upper Limit } \\
\hline \multicolumn{2}{|l|}{$\mathrm{pH}$} & & From 6,0 to 9,5 & \multicolumn{2}{|c|}{ Conforming } \\
\hline \multicolumn{2}{|c|}{ Turbidity } & uT & Up to 5,0 & \multicolumn{2}{|c|}{ Conforming } \\
\hline \multicolumn{2}{|c|}{ Nitrate } & $\mathrm{mg} / \mathrm{L}$ & Up to 10,0 & \multicolumn{2}{|c|}{ Conforming } \\
\hline \multicolumn{2}{|l|}{ Nitrite } & $\mathrm{mg} / \mathrm{L}$ & Up to 1,0 & \multicolumn{2}{|c|}{ Conforming } \\
\hline \multicolumn{2}{|c|}{ Total Ammoniacal Nitrogen } & $\mathrm{mg} / \mathrm{L}$ & Up to 1,5 & \multicolumn{2}{|c|}{ Conforming } \\
\hline \multicolumn{2}{|c|}{ Apparent Color } & $\mathrm{uH}$ & Up to 15,0 & \multicolumn{2}{|c|}{ Conforming } \\
\hline \multicolumn{2}{|l|}{ Sulfate } & $\mathrm{mg} / \mathrm{L}$ & Up to 250 & \multicolumn{2}{|c|}{ Conforming } \\
\hline \multicolumn{2}{|l|}{ Taste } & Intensity & Not Applicable & \multicolumn{2}{|c|}{ Conforming } \\
\hline \multicolumn{2}{|c|}{ Thermotolerant Coliform } & $\mathrm{NMP} / 100 \mathrm{ml}$ & Absence & \multicolumn{2}{|c|}{ No Conforming } \\
\hline \multicolumn{2}{|c|}{ Total Coliform } & NMP/100ml & Absence & \multicolumn{2}{|c|}{ No Conforming } \\
\hline \multicolumn{2}{|l|}{ Odor } & Intensidade & Not Applicable & \multicolumn{2}{|c|}{ Conforming } \\
\hline \multicolumn{2}{|c|}{ Total Dissolved Solids } & $\mathrm{mg} / \mathrm{L}$ & Up to 1000 & Conform & \\
\hline & & Methods C & Analysis and $\mathrm{Cr}$ & ementary & \\
\hline IdM & Methods of & Inalysis & Referen & Iethod & Finalization Date \\
\hline 1057 & Conductivity & & SMWW & 2510B & $03 / 02 / 2016 / 11: 42 \mathrm{~h}$ \\
\hline 1067 & $\mathrm{pH}$ & & SMWW & 4500B & 03/02/2016/11:40h \\
\hline 1074 & Turbidity & & SMWW & $2130 \mathrm{~B}$ & 03/02/2016/11:40h \\
\hline 1079 & Acidity & & SMWW & 2310B & $03 / 02 / 2016 / 11: 41 \mathrm{~h}$ \\
\hline 1081 & Coliforms by Mul & ple Tubes & SMWW 2 & 221B-G & 03/02/2016/11:07h \\
\hline 1083 & Apparent Color & & SMWW & $2120 \mathrm{D}$ & $03 / 02 / 2016 / 11: 43 \mathrm{~h}$ \\
\hline 1131 & Total Dissolved S & ids (TDS) & SMWW & $2510 \mathrm{~B}$ & $03 / 02 / 2016 / 11: 42 \mathrm{~h}$ \\
\hline 1178 & Taste & & SMWW & $2170 \mathrm{~B}$ & $03 / 02 / 2016 / 11: 43 \mathrm{~h}$ \\
\hline 1193 & Qualitative Colifo & & SMWW 2 & $221 \mathrm{~B}-\mathrm{G}$ & $03 / 02 / 2016 / 11: 05 h$ \\
\hline 1197 & Gallery & & Method Ga & $\mathrm{N} 15670$ & $03 / 02 / 2016 / 11: 41 \mathrm{~h}$ \\
\hline 1200 & Odor & & SMWW & $2170 \mathrm{~B}$ & $03 / 02 / 2016 / 11: 43 \mathrm{~h}$ \\
\hline
\end{tabular}


6) Results of laboratory analyses of the Marintuba River sample

Tables 7, 8, and 9 present information about the sample of the Marintuba River and the results of the analyses.

TABLE 7 COLLECTED SAMPLE INFORMATION

\begin{tabular}{|l|l|}
\hline \multicolumn{2}{|c|}{ Sample Id: 5358 - Sample N $\mathbf{0}^{\mathbf{0}}$ 834-1/2016.0 - Fluvial 2 - Capim Island - Abaetetuba - Stream Marintuba. } \\
\hline Type of Sample: Surface Water. & Matrix: Surface Water \\
\hline Collect Date: $27 / 01 / 2016 / 08: 05 \mathrm{~h}$ & Business Proposal: PC362/2016 \\
\hline Collect Point: Fluvial 2 - Capim Island - Abaetetuba - Stream Marintuba. & $\begin{array}{l}\text { Observation: Sample Collected and } \\
\text { Delivered by Applicant. }\end{array}$ \\
\hline Amount of Analysis FQ/ Micro: Microbiological and Physical-chemical & Amount of physical-chemical analyses: 1 \\
\hline Quantities of Microbiological Analysis: 1 & --- \\
\hline
\end{tabular}

TABLE 8 ANALYTICAL RESULTS

\begin{tabular}{|c|c|c|c|c|c|c|}
\hline \multicolumn{7}{|c|}{ Analytical Laboratory } \\
\hline Analysis & Unit & Result & LDM & LQP & IM & IdM \\
\hline $\mathrm{pH}$ & & 6,59 & & & & 1067 \\
\hline Turbidity & uT & 15,00 & & & & 1074 \\
\hline Apparent Color & $\mathrm{uH}$ & 163,0 & 3 & 3 & & 1083 \\
\hline Free Residual Chlorine & $\mathrm{mg} / \mathrm{L}$ & 0,00 & 0,04 & 0,04 & & 1086 \\
\hline Taste & & Not Applicable & & & & 1178 \\
\hline Thermotolerant Coliform & $\mathrm{NMP} / 100 \mathrm{ml}$ & Present & & & & 1193 \\
\hline Total Coliforms & $\mathrm{NMP} / 100 \mathrm{ml}$ & Present & & & & 1193 \\
\hline Chloride & $\mathrm{mg} / \mathrm{L}$ & 13,15543 & 0,05 & 0,05 & & 1197 \\
\hline Total Hardness & $\mathrm{mg} / \mathrm{L}$ & 20,48686 & 1,8 & 1,8 & & 1197 \\
\hline Iron & $\mathrm{mg} / \mathrm{L}$ & 0,46 & 0,002 & 0,002 & & 1197 \\
\hline Sulfate & $\mathrm{mg} / \mathrm{L}$ & 3,59353 & 0,05 & 0,05 & & 1197 \\
\hline Nitrate & $\mathrm{mg} / \mathrm{L}$ & 0,1 & 0,005 & 0,005 & & 1197 \\
\hline Nitrite & $\mathrm{mg} / \mathrm{L}$ & 0,03832 & 0,003 & 0,003 & & 1197 \\
\hline Total Ammoniacal Nitrogen & $\mathrm{mg} / \mathrm{L}$ & 0,02087 & 0,002 & 0,002 & & 1197 \\
\hline Total Alkalinity & $\mathrm{mg} \mathrm{CaCO}_{3} / \mathrm{L}$ & 112,88 & 2,6 & 2,6 & & 1197 \\
\hline Odor & Intensity & Not Applicable & & & & 1200 \\
\hline Conductivity & $\mu \mathrm{S} / \mathrm{cm}^{2}$ & 85,09 & & & & 1057 \\
\hline Dissolved Oxygen & $\mathrm{mg} / \mathrm{L}$ & 8,41 & & & & 1068 \\
\hline Acidity & $\mathrm{mg} / \mathrm{L}$ & 103,008 & & & & 1079 \\
\hline Total Dissolved Solids & $\mathrm{mg} / \mathrm{L}$ & 43,04 & & & & 1131 \\
\hline DBO & $\mathrm{mg} / \mathrm{L}$ & 27,02 & & & & 1166 \\
\hline
\end{tabular}

TABLE 9 SPECIFICATIONS AND OPINIONS

\begin{tabular}{|c|c|c|c|c|c|}
\hline \multicolumn{6}{|c|}{ Complete Ordinance 2.914} \\
\hline \multicolumn{2}{|c|}{ Analysis } & Unit & Limit & Opini & \\
\hline \multicolumn{2}{|c|}{ Chloride } & $\mathrm{mg} / \mathrm{L}$ & Up to 250 & Confo & \\
\hline \multicolumn{2}{|c|}{ Total Hardness } & $\mathrm{mg} / \mathrm{L}$ & Up to 500 & Confo & \\
\hline \multicolumn{2}{|l|}{ Iron } & $\mathrm{mg} / \mathrm{L}$ & Up to 0,3 & Not C & Limit \\
\hline \multicolumn{2}{|l|}{$\mathrm{pH}$} & & From 6,0 to 9,5 & Confo & \\
\hline \multicolumn{2}{|c|}{ Turbidity } & uT & Up to 5,0 & Confo & \\
\hline \multicolumn{2}{|c|}{ Nitrate } & $\mathrm{mg} / \mathrm{L}$ & Up to 10,0 & Confo & \\
\hline \multicolumn{2}{|l|}{ Nitrite } & $\mathrm{mg} / \mathrm{L}$ & Up to 1,0 & Confo & \\
\hline \multicolumn{2}{|c|}{ Total Ammoniacal Nitrogen } & $\mathrm{mg} / \mathrm{L}$ & Up to 1,5 & Confo & \\
\hline \multicolumn{2}{|c|}{ Apparent Color } & $\mathrm{uH}$ & Up to 15,0 & Confo & \\
\hline \multicolumn{2}{|c|}{ Sulfate } & $\mathrm{mg} / \mathrm{L}$ & Up to 250 & Confo & \\
\hline \multicolumn{2}{|l|}{ Taste } & Intensity & Not Applicable & Confo & \\
\hline \multicolumn{2}{|c|}{ Thermotolerant Coliform } & $\mathrm{NMP} / 100 \mathrm{ml}$ & Absence & $\mathrm{No} \mathrm{Cc}$ & \\
\hline \multicolumn{2}{|c|}{ Total Coliforms } & $\mathrm{NMP} / 100 \mathrm{ml}$ & Absence & $\mathrm{No} \mathrm{Cc}$ & \\
\hline \multicolumn{2}{|l|}{ Odor } & Intensity & Not Applicable & Confo & \\
\hline \multicolumn{2}{|c|}{ Total Dissolved Solids } & $\mathrm{mg} / \mathrm{L}$ & Up to 1000 & Confo & \\
\hline \multicolumn{6}{|c|}{ Methods of Analysis and Complementary Information } \\
\hline IdM & \multicolumn{2}{|c|}{ Method of Analysis } & \multicolumn{2}{|c|}{ Reference Method } & Finalization Date \\
\hline 1067 & \multicolumn{2}{|l|}{$\mathrm{pH}$} & \multicolumn{2}{|c|}{ SMWW $22^{\circ} 4500 \mathrm{~B}$} & 03/02/2016/10:59h \\
\hline 1074 & \multicolumn{2}{|l|}{ Turbidity } & \multicolumn{2}{|c|}{ SMWW $22^{\circ} 2130 \mathrm{~B}$} & $03 / 02 / 2016 / 10: 59 \mathrm{~h}$ \\
\hline 1083 & \multicolumn{2}{|l|}{ Apparent Color } & \multicolumn{2}{|c|}{ SMWW $22^{\circ} 2120 \mathrm{D}$} & 03/02/2016/11:04h \\
\hline 1086 & \multicolumn{2}{|c|}{ Free Residual Chlorine } & \multicolumn{2}{|c|}{ USEPA 330.5} & 03/02/2016/11:05h \\
\hline 1178 & \multicolumn{2}{|l|}{ Taste } & \multicolumn{2}{|c|}{ SMWW $22^{\circ} 2170 \mathrm{~B}$} & 03/02/2016/11:05h \\
\hline \multirow[t]{2}{*}{1193} & \multicolumn{2}{|c|}{ Qualitative Coliforms } & \multicolumn{2}{|c|}{ SMWW $22^{\circ} 9221 \mathrm{~B}-\mathrm{G}$} & 03/02/2016/16:05h \\
\hline & Gallery & & Método Gall & 15670 & 03/02/2016/11:03h \\
\hline 1200 & Odor & & SMWW $22^{\circ}$ & & 03/02/2016/11:06h \\
\hline
\end{tabular}




\begin{tabular}{|l|l|l|l|}
\hline 1057 & Conductivity & SMWW 22 $2510 \mathrm{~B}$ & $03 / 02 / 2016 / 11: 07 \mathrm{~h}$ \\
\hline 1068 & Dissolved oxygen & SMWW $22^{\circ} 4500$ O G & $03 / 02 / 2016 / 11: 00 \mathrm{~h}$ \\
\hline 1079 & Acidity & SMWW $22^{\circ} 2310 \mathrm{~B}$ & $03 / 02 / 2016 / 11: 07 \mathrm{~h}$ \\
\hline 1131 & Total Dissolved Solids (TDS) & SMWW $22^{\circ} 2510 \mathrm{~B}$ & $03 / 02 / 2016 / 11: 08 \mathrm{~h}$ \\
\hline 1166 & Branco de DBO & & $03 / 02 / 2016 / 11: 09 \mathrm{~h}$ \\
\hline
\end{tabular}

7) Comparison of the Results of the Analysed Samples with the parameters Established by Portaria 2914 of the Ministry of Health of Brazil

Table 10 presents the parameters analysed in the three points of collection in comparison with the limits established by ordinance 2914/11 and afterwards the opinion of each parameter.

TABLE 10 REPORTS OF PHYSICAL-CHEMICAL AND BACTERIOLOGICAL ANALYSES OF WATER (ANALYTICAL LABORATORY: MONTH FEB 2016).

\begin{tabular}{|c|c|c|c|c|c|c|}
\hline Analysis & Unit & $\begin{array}{l}\text { Rehearsal of } \\
\text { the stream. } \\
\text { Marintuba }\end{array}$ & $\begin{array}{l}\text { Rehearsal of } \\
\text { Community. } \\
\text { St }^{\circ} \text { Antônio II }\end{array}$ & $\begin{array}{l}\text { Rehearsal of } \\
\text { the stream. } \\
\text { Caratateua }\end{array}$ & $\begin{array}{c}\text { Ordinance } \\
\text { 2914/11- } \\
\text { Anvisa: } \\
\text { Limit }\end{array}$ & Opinion \\
\hline $\mathrm{pH}$ & & 6,59 & 6,05 & 7,01 & 6,0 to 9,5 & Conforming \\
\hline Turbidity & Ut & 15,00 & $\mathbf{0 , 0 2}$ & 16,00 & Up to 5,0 & $\begin{array}{l}\text { Não conforme para } \\
\text { superficiais }\end{array}$ \\
\hline Apparent color & $\mathbf{u H}$ & 163,0 & $\mathbf{0}$ & 145,0 & Up to 15,0 & $\begin{array}{l}\text { Not conforming upper } \\
\text { limit for superficial. }\end{array}$ \\
\hline $\begin{array}{l}\text { Free Residual } \\
\text { Chlorine }\end{array}$ & $\mathrm{mg} / \mathrm{L}$ & 0,00 & $\begin{array}{c}\text { Did not } \\
\text { present value }\end{array}$ & $\mathbf{0 , 0 0}$ & 0,2 a 2,0 & $\begin{array}{c}\text { Not conforming lower } \\
\text { limit }\end{array}$ \\
\hline Taste & & $\begin{array}{c}\text { Not } \\
\text { Applicable }\end{array}$ & $\begin{array}{c}\text { Not } \\
\text { Applicable }\end{array}$ & $\begin{array}{c}\text { Not } \\
\text { Applicable }\end{array}$ & $\begin{array}{c}\text { Not } \\
\text { Applicable }\end{array}$ & Conforming \\
\hline $\begin{array}{l}\text { Thermotolerant } \\
\text { Coliform }\end{array}$ & NMP/100mL & Present & $\begin{array}{c}\text { Present } \\
17,00\end{array}$ & Present & Absence & No conforming \\
\hline Total Coliforms & NMP/100mL & Present & $\begin{array}{c}\text { Present } \\
17,00\end{array}$ & Present & Absence & No conforming \\
\hline Chlorine & $\mathrm{mg} / \mathrm{L}$ & 13,15543 & 14,01674 & 8,03081 & Up to 250 & Conforming \\
\hline Total Hardness & $\mathrm{mg} / \mathrm{L}$ & 20,48686 & 13,46827 & 16,017 & Up to 500 & Conforming \\
\hline Iron & $\mathrm{mg} / \mathrm{L}$ & 0,46 & 0,45 & 0,41 & Up to 0,3 & $\begin{array}{l}\text { Não conforme limite } \\
\text { superior }\end{array}$ \\
\hline Sulfate & $\mathrm{mg} / \mathrm{L}$ & $\mathbf{3 , 5 9 3 5 3}$ & 12,17151 & 4,30116 & Up to 250 & Conforming \\
\hline Nitrate & $\mathrm{mg} / \mathrm{L}$ & 0,1 & 0,1 & 0,1 & Up to 10,0 & Conforming \\
\hline Nitrite & $\mathrm{mg} / \mathrm{L}$ & $\mathbf{0 , 0 3 8 3 2}$ & 0,05312 & $\mathbf{0 , 0 3 7 1 7}$ & Up to 1,0 & Conforming \\
\hline $\begin{array}{l}\text { Total Ammoniacal } \\
\text { Nitrogen }\end{array}$ & $\mathrm{mg} / \mathrm{L}$ & 0,02087 & $<0,002$ & $\mathbf{0 , 0 2 1 2}$ & Up to 1,5 & Conforming \\
\hline Total Alkalinity & $\mathrm{mg} \mathrm{CaCO}_{3} / \mathrm{L}$ & $\mathbf{1 1 2 , 8 8}$ & 83,22 & 100,52 & Up to 2,6 & \\
\hline Odor & Intensity & $\begin{array}{c}\text { Not } \\
\text { Applicable }\end{array}$ & $\begin{array}{c}\text { Not } \\
\text { Applicable }\end{array}$ & $\begin{array}{c}\text { Not } \\
\text { Applicable }\end{array}$ & 6 & Conforming \\
\hline Conductivity & $\mu \mathrm{S} / \mathrm{cm}^{2}$ & 85,09 & 75,07 & 57,07 & & \\
\hline Dissolved Oxygen & $\mathrm{mg} / \mathrm{L}$ & 8,41 & & 7,97 & & \\
\hline Acidity & $\mathrm{mg} / \mathrm{L}$ & 103,008 & 138,084 & 105,228 & & \\
\hline $\begin{array}{l}\text { Total Dissolved } \\
\text { Solids }\end{array}$ & $\mathrm{mg} / \mathrm{L}$ & 43,04 & 38,06 & 29,02 & Up to 1000 & Conforming \\
\hline DBO & $\mathrm{mg} / \mathrm{L}$ & 27,02 & & 23,05 & & \\
\hline
\end{tabular}

The results of the physical-chemical and microbiological analyses of one well and two streams evaluated, as well as the results of the analyses were extracted from the values presented according to the previous tables and compared according to the water potability standards of the 2914 of December 12, 2011 (Ministry of Health). The analytical results from the analytical laboratory enable a more detailed interpretation of the potability of water in the Capim Island region, as a jurisdiction of the municipality of Abaetetuba in the state of Pará. Based on these analyses and discussions, it is possible to identify the variables most representative of the environment study, as well as those that contribute in a less significant way to water quality assessment.

As observed in the tables resulting from the analyses of the three sites that serve as consumption for the Capim Island community, these results enabled a more detailed interpretation on the potability of water in the region of Capim Island.

The analytical result of the waters of the sources of consumption of the Marintuba and Caratateua streams, presented discrepancies that the ordinance 2914/2011 MS, the waters proved to be unfit for human consumption, considering that the turbidity, apparent coliform thermotolerant, had results above the allowed limit, since the alteration of thermotolerant coliforms is due to the leaching that carries animal faeces to the water body, and also the riverine culture of fosse constructions, directed directly to the bed of the rivers or consequences of the high tides. 
In the Santo Antônio II Community, it was observed that the turbidity, apparent color, free residual chlorine, is in compliance with the acceptable physicochemical parameters confirmed by the analytical results of the laboratory. However, traces of free residual chlorine were observed due to the periodic washing of the well with chlorine (Bleach water). The presence of thermotolerant coliforms in the Santo Antônio II community sample determines the improper character of this natural good for consumption.

What it refers to heavy materials in the water body, this may be due to the location of the Capim Island on the intelligence of the tides, which are bathed by the Albrás-Alunorte power plant, where there may be possible contamination of the rivers. Another aggravating point is the irregular disposal of batteries in general of the riverine populations in the water body, constituting the danger to the health of the riverside community. However, the citation is due to the lack of results of the analysis of heavy materials, an analysis that the laboratory did not have at the moment. Finally, the viable solution for the Capim Island community is the alternative treatment of water used for human consumption, within the criteria of Ordinance 2.914 / 2011 of the Ministry of Health.

\section{Implementation of the Handmade Filter with A Pet Bottle in the Capim Island Community}

\section{1) Objective and Materials}

The purpose of this deployment is to help and teach how blending separation techniques are applied in water treatment systems. To do this, you must show the community how to install the filter using the following materials and reagents:

- 3 Bottles of soda of $2 \mathrm{~L}$;

- Thin Sand;

- Coarse Sand;

- Small stones well washed (if they are dirty, the result of the experiment will be compromised);

- Active Coal;

- Cotton;

- Soil;

- Water;

- Saturated aluminum sulphate solution (aluminum sulphate can be found at places that sell pool materials);

- Saturated calcium hydroxide solution (hydrated lime or calcium hydroxide, can be found in building materials stores and should be handled with care. To get your solution, simply add small amounts of hydrated lime to the water);

- Plastic Spoons.

\section{2) Experimental Procedure for System Assembly}

1. The bottles are cut in half so as to form the containers as shown in Fig. 8. The bottle D should have a side hole near the top. The ends that may be sharp should, preferably, be wrapped with a tape.

2. The filter is set to part $\mathrm{C}$ as shown in the diagram below (bottom to top: $10 \mathrm{~cm}$ of dry cotton, 1 thin layer of active charcoal, $2 \mathrm{~cm}$ thick layer of fine sand, $2 \mathrm{~cm}$ thick coarse sand and $4 \mathrm{~cm}$ thickness). Remember that the filter must be moist before starting the experiment;

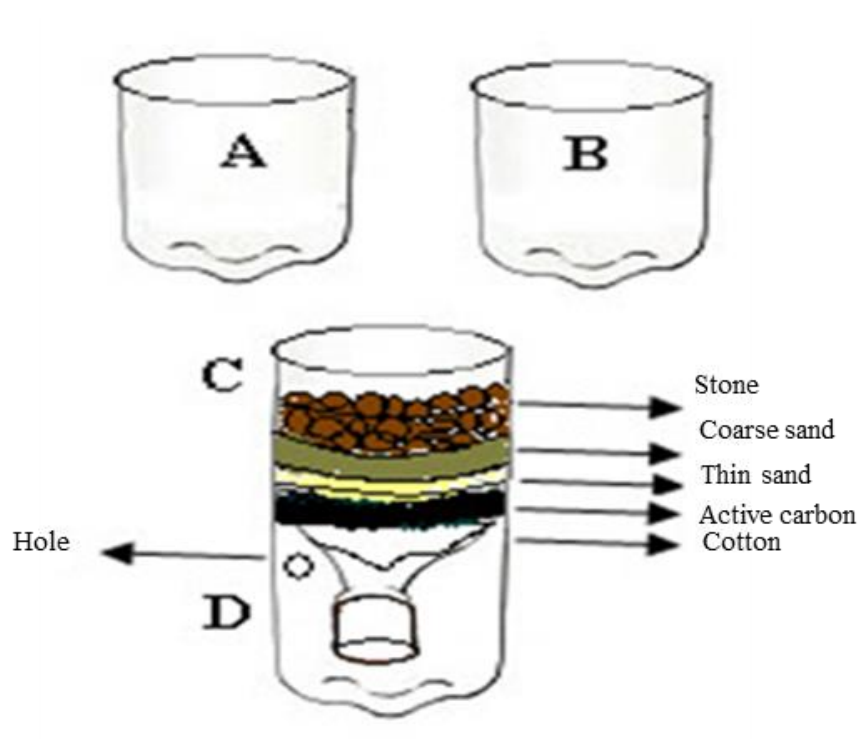

Fig. 8 Building Filter (https://educador.brasilescola.uol.com.br) 
3. Mix a spoon of soil with $100 \mathrm{~mL}$ of water in the container $\mathrm{A}$;

4. Wait 5 minutes and pour the liquid from the upper phase into container B;

5. Add 1 spoon full of aluminium sulfate and one spoon of calcium hydroxide under stirring to container B;

6. Let the container stand and observe what happens after a few minutes;

7. Transfer the liquid from the upper phase to container $\mathrm{C}$ (layered filter);

8. Collect the filtrate in the container.

With this procedure it is possible to relate the processes made with the separation methods that can be explained to the community and in the respective stages of water treatment. At first it is convenient to leave the mixture at rest and after some time transfer only the upper phase to another container. At the water treatment plant the decantation is applied to the deposition of the dirt flakes on the bottom of the decanter, making sure that the water is safe for consumption.

\section{CONCLUSIONS}

As can be seen, throughout this work, water is an essential element for the preservation of life on the face of the Earth. Because this is so, the human being has the duty to guard and preserve this precious asset, which guarantees survival. For this to happen, it is necessary to respect and care for the environment, doubled attention in regard to the preservation of the water environment, avoiding that factors caused by certain human actions, will affect aquatic life, causing the devastating pollution of the survival medium of beings in general. In this sense, it was verified that the physical, physical-chemical and microbiological analyses carried out in the Capim Island community, in a well and two streams, gave as results of the analyses obtained from the values presented throughout the tables, that some elements presented discrepancies of drinking water standards, a result that is not in line with what is stated in Ordinary 2914 of December 12. 2011 (Ministry of Health).

The analytical results provided by the laboratory allow a more detailed interpretation of the potability of water in the region of Capim Island, in the municipality of Abaetetuba, in the state of Pará. Based on these analyses and discussions, it is possible to identify the most representative variables of the studied environment, as well as those that contribute in a less significant way to water quality assessment. The ordinance 2914 of December 12, 2011 (MS) it was used as reference for evaluation of the results of the parameters that are contemplated.

The analytical result of the waters of the sources of consumption, which form the superficial spring, which bathes Capim Island, more precisely the steams of Marintuba and Caratateua, are not in agreement with what is the ordinance 2914/2011 MS, because, according to the ordinance, those waters, through analysis, prove to be not allowed for human consumption, since: turbidity, apparent color, thermotolerant coliform, present results above the allowed limit, a factor that has as natural characteristic of the region of the low Tocantins, since the geological formation of the region finds periodic transformations; since the alteration of thermotolerant coliforms is due to the leaching that carries animal feces to the water body, and also the riverine culture of fosse constructions, directed directly to the bed of the rivers or consequences of the high tides.

In the Santo Antônio II Community, there is a perforated well (handmade), which functions as a collection place, observing turbidity, apparent color, free residual chlorine, within an acceptable physicochemical parameter, which could be verified after the result analytical. However, traces of free residual chlorine were observed due to the periodic washing of the well with chlorine (bleach water). The presence of thermotolerant coliforms in the Santo Antônio II community sample determines the improper character of this natural good for consumption.

One point to be mentioned is the possible presence of heavy materials in the water body. This may happen, due firstly to the location of Capim Island on the intelligence of the tides, which are bathed by the Albrás-Alunorte power plant, where there may be contamination of the rivers. Another point is the irregular disposal of batteries in general of the riverside populations in the water body. This is a type of "Culture" that is practiced over many years. However, the citation is due to the lack of results of the analysis of heavy materials, an analysis that the laboratory did not have at the moment. Finally, the viable solution for the Capim Island community is the alternative treatment of water used for human consumption, within the criteria of Ordinance 2.914/2011 of the Ministry of Health. Another point of fundamental importance is the awareness that must be realized through lectures, having as points: caution should be taken when disposing of electronic waste and dumping in streams and rivers in the region that can seriously affect the health of the community caused by the possible acidic dissolution of heavy metals such as arsenic, cadmium, lead, mercury, etc. which are present in cell phones, computers and other equipment of common use; implantation of filters in the community to contribute and teach how the separation techniques of blends are applied in water treatment systems. Therefore, it is necessary to show to the community how to install the filter to be used in the treatment of water for daily consumption.

\section{ACKNOWLEDGMENT}

The authors thank the Pro-Rectory for Research and Post-Graduation (PROPESP) by the encouragement and financial support of this article. 


\section{REFERENCES}

[1] V. P. S. Freitas, B. M. Brígido, M. I. C. Badolato and J. Alaburda, "Padrão físico-químico da água de abastecimento público da região de Campinas" Rev. Inst. Adolfo Lutz, vol. 61(1), pp. 51-58, 2002

[2] Agência Nacional de Águas (ANA), Planos de Recursos Hídricos e Enquadramento dos Corpos de Água, Brasil, Brasília, Cadernos de Capacitação em Recursos Hídricos, vol, 5, 2013.

[3] Companhia de Tecnologia de Saneamento Ambiental CETESB), Levantamento sanitário das bicas localizadas em Santos, Brasil, São Paulo, Relatório técnico, SENG/GAS/047/78, pp. 121, 1978.

[4] M.T.P. Razzolini and W.M.R. Gunther, "Impactos na saúde das deficiências de acesso a água", Saúde Soc., São Paulo, vol.17 (1), pp. 21-32, 2008.

[5] BR. Ministério da Saúde, Portaria $\mathrm{n}^{\circ}$ 2914, Dispõe sobre os procedimentos e responsabilidades relativos ao controle e vigilância da qualidade da água para consumo humano e seu padrão de potabilidade, Brasil, Brasília, Diário Oficial (da) República Federativa do Brasil, 2011. [Online] Available : http://www.comitepcj.sp.gov.br/download/Portaria_MS_2914danos à saúde de seus usuários.

[6] B. H. L. Batalha and A. C. Parlatore, Controle da qualidade da água para consumo humano: bases conceituais e operacionais, Brasil, São Paulo: CETESB, p.198, 1993.

[7] M. Von Sperling, Lodos ativados - Princípios do tratamento biológico de águas residuárias. Brasil, Belo Horizonte: Departamento de Engenharia Sanitária e Ambiental; Universidade Federal de Minas Gerais; vol. 4, 1997.

[8] J. Manuel Filho, Hidrogeologia: Conceitos e Aplicações, CPRM. cap. 2. p. 13-33, 2nd ed, 1997.

[9] S. M. D. Souza, Qualidade de água para cultivo de peixes, Porto Alegre, Brasil: Editora UFRGS, 2010.

[10] L. V. Arana, Princípios químicos de qualidade de água em aqüicultura: uma revisão para peixes e camarões, Florianópolis, Brasil: Editora da Universidade Federal de Santa Catarina, 1997. 